\title{
TRIAL AND ERROR EDITED BY F SHAPIRO AND J GARRY
}

Reviewed by Sandra Petersson*

Fred Shapiro and Jane Garry (eds) Trial and Error: An Oxford Anthology of Legal Stories (Oxford University Press, Oxford, 1998). Hardcover, $479+$ xii pages, \$NZ50.

Some ten years ago, I had the fortune to find a boxed set of Ephraim London's law and literature anthology, The World of Law. ${ }^{1}$ It sat on a bottom shelf, anchoring an otherwise uninteresting collection of battered law books, in a store not unlike Christopher Morley's Haunted Bookshop. ${ }^{2}$ London's bright red books had been marked down to $\$ 20$, box and all. If nothing else, I thought, they look nice. I bought them. I read them. I treasure them. Sometimes it pays to judge books by their covers.

The World of Law remains an important law and literature anthology. Its two volumes, The Law in Literature and The Law as Literature, delineated the constituent fields of the emerging discipline. The publication of James Boyd White's The Legal Imagination provided the theoretical framework for developed analysis. ${ }^{3}$ While, the majority of "law \& lit" books published in recent years have examined the as-side, applying literary analysis to legal texts, a few have considered the in-side, bringing together new texts on the law in literature.

* Senior Lecturer in Law, Victoria University of Wellington.

1 Ephraim London (ed) The World of Law: A Treasury of Great Writing about and in the Law (Simon \& Schuster, New York, 1960). The anthology is further sub-subtitled Short Stories, Plays, Essays, Accounts, Letters, Opinions, Pleas, Transcripts of Testimony - From Biblical Times to the Present.

2 A sign in Morley's fabled shop declared "We have what you want, though you may not know you want it": Christopher Morley The Haunted Bookshop (1920).

3 James Boyd White The Legal Imagination: Studies in the Nature of Legal Thought and Expression (Little Brown \& Co, Boston, 1973) 
The collection of new law in literature texts is of great assistance to both the scholar and casual reader. As Justice Frankfurter once advised "The best way to prepare for the law is to come to the study of law as a well-read person." 4 Three excellent anthologies are currently available: Jay Wishingrad's Legal Fictions, ${ }^{5}$ Lenora Ledwon's Law and Literature, ${ }^{6}$ and Fred Shapiro's and Jane Garry's Trial and Error. ${ }^{7}$

In Trial and Error, Shapiro and Garry have brought together 32 short stories and extracts from longer works of fiction and non-fiction. Shapiro is a lecturer in legal research and a librarian at Yale Law School, and the editor of The Oxford Dictionary of American Legal Quotations. ${ }^{8}$ Garry is an editor for the Greenwood Publishing Group. Their book is not intended as a comprehensive collection of legal stories. ${ }^{9}$ The stories have been selected to highlight the trial process and to present "individuals caught up in the legal system as practitioners, participants, and sometimes victims." 10 Within this context one would expect selections from Kafka or Dostoyefsky. However, Shapiro and Garry have chosen to limit the book's scope to works originally written in English. ${ }^{11}$ In so doing, they achieve an admirable balance among British, American, and Commonwealth writers. The stories cover the period from 1827 to 1993, however, the collection retains a modern edge with half of the stories published after 1950 .

While the book's scholarly qualities cannot be understated, this is first and foremost a book to be enjoyed. The imaginative plot twists in Agatha Christie's "The Witness for the

4 Felix Frankfurter "Advice to a Young Man Interested in Going into Law" in The World of Law, above n 1, II: 725.

5 Jay Wishingrad (ed) Legal Fictions: Short Stories About Lawyers and the Law (reissued ed, Overlook Press, Woodstock, 1994).

6 Lenora Ledwon (ed) Law and Literature: Text and Theory (Garland Publishing, New York, 1996).

7 Fred Shapiro and Jane Garry (eds) Trial and Error: An Oxford Anthology of Legal Stories (Oxford University Press, Oxford, 1998) [Trial and Error].

8 Fred Shapiro The Oxford Dictionary of American Legal Quotations (Oxford University Press, New York, 1992).

9 For a thorough annotated bibliography of law stories, see Elizabeth Villiers Gemmette Law in Literature: Legal Themes in Short Stories (Greenwood Publishing Group, Westport, CT, 1992).

10 Trial and Error, above $\mathrm{n}$, vii.

11 For a collection of foreign texts, see Wishingrad under "Lawyers and the Law: Other Voice, Other Countries", above n 5, 285. 
Prosecution" (1924), the extract from John Barth's The Floating Opera (1956), and Michael Gilbert's "Mr Portway's Practice" (1958) are delightful escapism, yet not implausible. As proof that legal truth is stranger than fiction, I was amazed that Mark Twain's "Great Landslide Case" (1872) presented the same obscure point of law as a case I once encountered - where a landslide deposits Blackacre directly on top of Whiteacre, who holds title to the resulting property? In Twain's imaginary case, the issues were black and white and superior title was determinable. However, the real case was not so simple, the Crown having asserted title to the minerals in the rocks that had fallen from or onto the property.

In contrast to such tales of fancy, Trial and Error also includes stories of poignant realism woven from actual events. An interesting pair of such stories is found in the extracts from Harper Lee's To Kill a Mockingbird (1960) and Ernest J Gaines A Lesson Before Dying (1993). In each, a black man stands accused before an all-white jury in the American South; the reader is never left in doubt as to the eventual verdict, though the only "offence" committed was that the accused was in the wrong place at the wrong time. A shockingly similar effect of dislocation and inevitability is also created by Rebecca West in "Greenhouse with Cyclamens I" (1955). She writes: "It seemed ridiculous for the defendants to make any effort to stave off the end, for they admitted by their appearance that nothing was to go well with them again on this earth."12 However, in West's account the defendants are Nazi leaders on trial at Nuremberg.

The anthology includes several classic law in literature texts. For example, in the extract from Bleak House (1853), Charles Dickens invokes the ghosts of barristers past, all: ${ }^{13}$

mistily engaged in one of the ten thousand stages of an endless cause, tripping one another up on slippery precedents, groping knee-deep in technicalities, running their goat-hair and horse-hair warded heads against walls of words, and making a pretence of equity with serious faces?

Texts by Sir Walter Scott, George Eliot, Herman Melville, and Robert Louis Stevenson are also included. However, the book successfully combines these standard law and literature texts with newer stories by women and African Americans. The result is a complex and challenging portrait of the law.

The stories in Trial and Error form an excellent basis on which to begin a study of law in literature, either for personal interest or as part of a formal course of study. It is also a book

12 Trial and Error, above n 7, 254-256.

13 Trial and Error, above n 7, 28. 
with a long shelf-life, though prolonged storage should be avoided. Repeated and regular use will reveal and increase the book's value. 